\title{
シンポジウム
}

\section{3. 肝炎ウイルスの臨床}

\section{司会 埼玉医科大学第三内科 藤原研司 \\ 司会 愛知医科大学第一内科 各務伸一}

\section{司会者のことば}

我が国における肝疾患の多くは肝炎ウイルス の感染に起因する. 特にHAV, HBV, HCVが 重要であるが, 新たに発見されたGB-C/HGVや TTVも注目されている.

HAV, HBVの一過性感染で発症する急性肝 炎は，大部分はウイルスが排除されて自然治癒 するが, 一部では劇症化し, 救命に向けた集学 的治療が行われている，HBVキャリアの急性 発症や成因ウイルス不明の劇症肝炎では予後は 極めて不良で, 肝移植も治療選択となっている. HCVは感染後に高率に慢性化するので, 早期 対策が重要である。

HBV, HCV感染が持続している場合には, 無症候性に経過することもあるが，壞死，炎症 を繰り返すと慢性肝炎から肝硬変へと進展す る.インターフェロン（IFN）療法のB型慢性 肝炎に対する効果は不十分で，ラミブジンなど
の新たな抗ウイルス療法が導入されている，C 型慢性肝炎ではIFN療法により治痹する場合も あるが，約70\%は難治性で投与方法の工夫やリ バビリンなど他の抗ウイルス薬との併用療法が 検討されている。これらが肝硬変になると肝細 胞癌を高率に発症するので, その早期発見・治 療が肝要である。

近年, 肝炎ウイルスは肝以外の臓器にも障害 をおこすことが明らかになってきた．特に， HCVに上る免疫異常, 心, 腎, 皮眉, 粘膜な どの病変が話題となっている.これら疾患に対 して抗ウイルス薬を中心とした治療法を確立す る必要がある。

肝炎ウイルス感染は多彩な病態を呈するだけ に，日常診療における適切な診断と治療が求め られる。本シンポジウムではこれらの点に関す る現況をまとめ，今後の課題を明確にしたい.

\section{1）肝炎ウイルスの現況}

\section{東京大学感染症内科 小池和彦}

現在，A， B， C, D, E型の 5 種類の肝炎ウ イルスが存在する。近年, GBウイルス-C, TT ウイルス, SEN-Vといった肝炎ウイルスの候補 が発見されているが，それらのいずれもまだ肝 炎ウイルスとしては認められていない。
A型肝炎ウイルス（HAV）は，我が国にお ける急性肝炎の最大の原因である. 近年, HAV に対する抗体陽性率の低下 · 高齢者へのシフト が見られ，高齢者のA型肝炎が従来に比べて増 加してきている. 重症化・劇症化肝炎にHAV 
の占める割合の増加の原因となっている．臨床 的治痹後も長期にわたって糞便中へウイルスを 排出する例が存在し，HAVの供給源になって いる可能性も指摘されている. B型肝炎ウイル ス（HBV）は，遺伝子DNAを宿主遺伝子中に 組み込むこと，X遺伝子という発がん関連遺伝 子をもつことから，肝炎ウイルスの中では最も がんウイルスとしての特質をもっているといえ る. 従来使用されてきた抗原・抗体系による診 断学に改定が必要な状況となっている。また， $\mathrm{HBV}$ 急性感染と HBVキャリアとの境界線もま た引き直さなけれならないようである．C型肝 炎ウイルス (HCV) 感染の新規の発生は減少
しているが，関連した肝細胞癌の発生は年々増 加してきており，我が国では医療・社会上最も 大きな問題となっている肝炎ウイルスである. $\mathrm{HCVが}$ 肝発癌に直接的に関与しているか否か は議論が続いているが, 最近, HCVのコア蛋 白が肝発癌性をもつことが示され，HCVの直 接的関与が示唆されている。D型肝炎ウイルス は, HBVへの重複感染でのみ感染を起こすが, 我が国においては症例が極めて少なく，臨床上 問題となることも稀である。 E型肝炎ウイルス は上水道を通じて感染するため，我が国での集 団発生はない. 輸入感染症としての意義をもつ. これら肝炎ウイルスの現況について紹介する.

\title{
2）急性肝炎，劇症肝炎の話題
}

\author{
埼玉医科大学第三内科 持田 智
}

本邦の急性肝疾患は大部分が肝炎ウイルス感 染に起因するが，自然治癒する急性肝炎から， 広沉肝壊死を呈して致死率の高い劇症肝炎ま で，その病態は多彩である.プロトロンビン時 間が40\%以下を示す急性肝炎重症型は，約30\% でI度以上の肝性脳症を発症し, 劇症肝炎へと 移行する. A, B型の急性肝炎で末梢血血小板 数が低值の症例では，肝類洞内凝固による微小 循環障害が肝壊死進展に関与していると推察さ れ，抗凝固療法により劇症化を阻止できる場合 がある. B型肝炎ウイルスcarrierの急性増悪例 では，ラミブジンなど抗ウイルス療法が劇症化 の子防法として期待される．また，劇症化した 症例でも, 脳症出現までの期間が10日以内の急 性型では, 人工肝補助療法や多蔵器不全に対す る集学的治療で肝不全期を乗り切れば, 肝再生 が生じて約 $50 \%$ 症例を救命することが可能で ある。
一方，脳症出現までの期間が長い㖇症肝炎要 急性型は, 肝再生不全を高率に併発し, 予後が 極めて不良である。これら症例の多くは，成因 が非A-G型肝炎ウイルス感染に分類され，血清 マーカー陰性のB型肝炎ウイルスや自己免疫性 肝炎の関与が注目されている。 また，新たな肝 炎ウイルスであるTTV感染が原因の症例も存 在する可能性がある. 覀急性型の症例で，日本 急性肝不全研究会のガイドラインで死亡と予測 された場合には，速やかに脳死ないし生体部分 肝移植を実施することが, 救命のためには必須 と言えよう。

なお，C型肝炎ウイルスによる急性肝炎は重 症化しないものの慢性化する頻度が高い. 近年 は減少傾向にあるが，医療事故などでの感染例 で慢性化が疑われる場合は，インターフェロン 療法で対処する. 


\title{
3）B型慢性肝疾患の話題
}

\author{
愛知医科大学第一内科 石川哲也
}

B型肝炎ウイルス（HBV） は直接の細胞障害 性を持たないため, その病態を決定するのは主 に宿主の免疫応答であるとされている，実際，

トランスジェニックマウスを用いた研究などよ り, 肝細胞障害とウイルスの排除に宿主のHBV 抗原特異的免疫応答が梁く関わることが示され ている.一方では, ウイルスの変異が病態に密 接に関与することが明らかになってきた，HBe 抗原産生能の劣る変異株がseroconversionに関 与することなどである，しかし，何故，無症候 性キャリアから肝炎を発症するかなど不明の点 も多く, B型慢性患疾患の多様な病態を完全に 解明するまでには，まだ時間がかかりそうであ る.

$\mathrm{B}$ 型慢性肝疾患における臨床上の一番の問題 点は，決め手となる治療法が確立されていない ことである. 従来のinterferon, propagermanium, ステロイド離脱療法などは，未だにス夕 ンダードな治療法とはなり得ていない。一方で, 最近，免疫賦活薬であるthymosin $\alpha 1$ や逆転写 酵素阻害剤であるlamivudineの有用性が確認さ れている，特にlamivudineは耐性変異株の出現 という問題点もあるが, 有用性は高く, 今後, 投与法や適応が広く検討されるべきであろう. 視点を変えた新しい治療法として，宿主の免疫 応答を利用する方法も近年試みられている．細 胞障害性Tリンパ球のエピトープを含むペプタ イドワクチン, あるいは従来感染予防の目的で 用いられてきたHBs抗原ワクチンをキャリアの 治療に用いる方法などである.マウスにおいて は，DNA，あるいは樹状細胞を用いた更に強 力な免疫法も検討されている．また，IL-12に よる治療もマウスモデルにおいては有用性が確 認されている。これらの臨床応用に向けた，更 なる研究の進展が待たれるところである.

$\mathrm{B}$ 型慢性肝疾患の治療法の確立は発癌予防の 観点からも重要である. 病態の完全な解明と, それに基づく治療法の早急な確立が望まれる.

\section{4） C型慢性肝疾患の話題}

\section{大阪大学分子制御治療学 林 紀夫}

C型肝炎ウイルス (HCV) 持続感染者は200 万人以上存在すると推定され, 肝細胞癌の約 70 \%はHCV持続感染による慢性肝疾患を基礎病 変として発生し，2010～2015年まで肝細胞癌は 増加すると推測されている．1992年よりC型慢 性肝炎に対しインターフェロン（IFN）治療が 広く行われてきたが，IFN治療の究極の目標は 肝細胞癌の抑制である. IFN治療後の肝細胞癌 発生率を検討すると, 無効群では経年的に漸增
したが, 著効, 再燃群においては低率であった. IFN治療により一時的にでもトランスアミナー ゼの正常化をきたした例，すなわち再燃群にお いて無効群に比し有意に肝細胞癌併発率が低率 であったことは大変興味深い、肝発癌を阻止す るには, 究極的にはウイルスの排除を目指すこ とであるが, 肝細胞死を抑制できれば肝細胞癌 の発生を減少させることも可能である.

HCV特異的CTLははウイルス感染細胞の排 
除において最も重要なエフェクター細胞だが, 多くのC型肝炎患者においてCTLが存在するに もかかわらず, HCVが排除できないこのこ とは, HCV特異的CTLの誘導が, C型肝炎患者 に扔いて不十分であることを示唆する。このよ うなCTL機能の抑制には, 強力な抗原提示細 胞である樹状細胞のIL-12産生低下によるアロ 抗原刺激能の低下やIL-10の高值が関与してお り,これらの制御がC型肝炎難治例の治療に役 立つ可能性がある。

一方, 無効群では肝発癌は抑制されず，再燃 群でもさらに経過観察を続けると肝発癌は増加
すると予測され，肝発癌の機構を分子レベルで 明らかにする必要がある. 現在のところ $\mathrm{HCV}$ により肝炎が持続し, 肝細胞死・肝細胞增殖を 繰り返すことにより突然変異が起こり，その細 胞がアポトーシスにより排除されずクローナル に増殖することにより肝癌が高率に発症すると 考えられている.アポトーシスによる肝癌細胞 の排除の抑制に関しては，HCVのコア蛋白な どによる抑制機序が明らかにされつつあるが, 今後の検討が肝発癌機構の解明やその制御に役 立つものと思われる。

\section{5）肝炎ウイルスによる心，腎，血管病変}

\section{京都大学循㻒病態学 松森 昭}

肝炎ウイルス感染でみられる肝外症状には, 結節性多発動脈炎, 本態性混合クリオグロブリ ン血症，系球体腎资などが知られ，B型肝炎ウ イルス，C型肝炎ウイルスいずれの感染におい てもみられる.

われわれは，心筋症におけるC型肝炎ウイル ス感染の意義を検討してきたが, 拡張型心筋症, 肥大型心筋症で高頻度にC型肝炎ウイルス抗体 が検出された。 また，心筋のホルマリン固定, パラフィン切片からC型肝炎ウイルスゲノムを 検出する方法を確立した結果，心筋症の生検・ 剖検心筋からC型肝炎ウイルスRNAが高頻度に 検出され，(+) 鎖のみならず（）鎖も検出 し, C型肝炎ウイルスが心筋内で増殖する可能 性が示唆された．C型肝炎ウイルスによる心筋 症では肝炎のみられない例も多く, 臓器特異的 なウイルスゲノムの存在が考えられるととも に, HLAとの関連から宿主の免疫応答性重要 性が考えられた。ささに，C型肝炎ウイルス抗 体陽性例では心筋症以外の心異常をきたす可能
性が示唆された。また，C型肝炎ウイルス肝炎 と同時に心筋障害のみられた症例に対し，イン ターフェロン治療を試み, その有効性が示唆さ れている。

C型肝炎ウイルスによる腎病変としては膜性 增殖性腎炎が報告されてきたが，われわれの研 究では膜性腎症においてもC型肝炎ウイルス感 染を高頻度に認め, 腎生検組織からC型肝炎ウ イルスRNAの (+) 鎖抢よび（一）鎖を検出 した。C型肝炎ウイルス感染群では間質の線維 化, 細胞浸潤が高度であり, 間質病変を伴うこ とが示唆された。また，C型肝炎，間質性腎炎， 心筋症を同時に発症し各臓器からC型肝炎ウイ ルスゲノムが検出された例もある.

B型肝炎ウイルス感染では結節性多発動脈炎 を伴うことがあり，とくに肝，腎の動脈病変の 頻度が高いとされている．クリオグロブリン血 症を伴う場合は, クリオグロブリンの血管壁へ の沈着による血管炎もみられる。 


\section{6）肝炎ウイルスによる皮虐，粘膜，筋，造血器病変}

\section{久留米大学第二内科 佐田通夫}

肝炎ウイルスは, 肝臟ばかりでなく他の臓器 や組織にも障害を引き起こすことが知られるよ うになりこれらを総称して肝外病変と呼んで いる. 特にC型肝炎ウイルス（HCV）は，さま ざまな肝外病変を引き起こすことが知られてい るが，その多くは発症機序がまだ明らかにされ ていないわかっていることは，HCVが肝細 胞だけでなくリンバ球をはじめとする種々の細 胞や瀻器に感染し，さらに増殖すること，そし てHCV感染が自己抗体の出現率を高めること である．また肝外病変の発現やその機序を説明 できる実験結果として, HCVのエンベロープ 遗伝子導入マウスに慢性唾液腺炎が起こり, 導 管上皮の細胞質内にHCV El蛋白が発現するこ とがある.これらは，HCV感染に肝外病変が 多い理由や機序を考えるうえで, 重要な現象で あり実験結果と思われる.

A型肝炎ウイルスによる肝外病変として, 急 性腎不全, 造血器障害（赤芽球疼, 再生不良性 䂓血, 溶血性貧血, 特発性血小板減少性紫斑病),
心筋障害, 䯣膜炎, 檤膜脳炎, Guillain-Barré 症候群, 滕炎, 自己免疫性肝炎の誘発, 耐糖能 異常などを，またB型肝炎ウイルスによる肝外 病変として, 堅障害, 多発性動脈炎, Gianotti 病, 慢性関節リウマチ, Schönlein-Henoch紫斑 病, 多発性筋炎, 造血器障害（血小板減少症, 再生不良性貧血）を, HCVの肝外病変として は, クリオグロブリン血症, 膜性增殖性系球体 腎炎, 晚発性皮㲊ポルフィリン症, Sjögren症 候群, 悪性リンパ腫, 筋炎, 口腔癌, 扁平苔痽, モーレン角膜潰瘍，心筋障害，糖尿病，間質性 肺炎などを挙げることができる.

肝炎ウイルスによる肝外病変の研究は，原因 が解明されていない疾患の概念や治療法を確立 するばかりでなく，まだ不明な点の多い肝障害 機序を解明する糸口を提供する可能性を持って いる.

今回は，ここに示す疾患のうち，特に皮痛， 粘膜, 筋, 造血器障害を中心に述べる. 